\title{
Semblanza Juan Marconi Tassara
}

\author{
Alberto M inoletti S. ${ }^{1}$
}

El Dr. Marconi, el Profesor Marconi, el Profe, o el Sheriff para sus más íntimos. Un hombre de esos que caminan por la vida sin poder evitar que una profunda huella quede a su paso. Su partida, para nosotros sus discípulos, nos provoca múltiples imágenes, emociones y reflexiones, tal como lo hizo en su vida profesional.

Marconi, el de las ideas geniales. Un apasionado de la salud mental y la psiquiatría, multifacético, podía devorar conocimientos de libros y revistas científicas junto con una perspicaz mirada de la realidad de las personas y comunidades, produciendo nuevos conceptos, visiones, formas de afrontar la realidad que nosotros no sospechábamos o que solo logramos realmente comprender después de algunos años.

Lo vimos, y lo acompañamos, en el mundo de la epidemiología, en los primeros estudios chilenos que permitieron medir la magnitud de los trastornos mentales y su relación con el nivel socioeconómico, pioneros en Latinoamérica. Supimos que había hecho estudios experimentales de los mecanismo neurofisiológicos de la apetencia del alcohol. Leímos en la década del 60 su teoría estructural de las psicosis, la cual se ha publicado en la revista de la Sociedad de N eurología y Psiquiatría 40 años después, manteniendo su vigencia y frescor conceptual. Escuchamos sus explicaciones de la teoría del calcetín para la reforma de la enseñanza de la medicina, durante las convulsiones universitarias del 68.

También aplicamos sus definiciones y enfoques clínicos sobre el alcoholismo inveterado y el in- termitente, que hicieron historia en Chile en varias generaciones de profesionales de la salud, y recibimos sus enseñanzas clínicas en aquellas enfermedades mentales más difíciles de diagnosticar y tratar. Nos entusiasmamos y nos comprometimos con sus programas intracomunitarios de salud mental, donde se conjugaban la sabiduría popular y la medicina occidental, la población participaba activamente en la solución de sus problemas, facilitándose la formación de líderes y el desarrollo de organizaciones de autoayuda.

Marconi, el maestro. Con su producción intelectual hubiera podido cosechar en Chile y en otros países más honores y algunas riquezas. Sin embargo, prefirió sembrar en los espíritus, a través de la formación de numerosos profesionales, técnicos y líderes comunitarios, durante medio siglo de docencia, para que el país recibiera en el siglo 21 los frutos del desarrollo de Planes Nacionales de Salud M ental.

Aún nos sorprendemos al conversar con profesionales de salud que recibieron las enseñanzas de Marconi y que nos cuentan con orgullo como desarrollaron programas de prevención y tratamiento del alcoholismo en algún rincón de Chile. Como también nos causa sorpresa el descubrirnos aplicando aún hoy día sus enseñanzas de Antropología y de relativismo cultural en nuestro trabajo con distintos grupos humanos. Como no recordar sus cuestionamientos a las terapias psicoanalíticas y sus enseñanzas innovadoras sobre las terapias conductuales, en los albores de

1 Jefe Departamento Salud M ental. División de Prevención y Control de Enfermedades. Subsecretaría de Salud Pública. Ministerio de Salud. 
Eysenck y Wolpe, terapias que 40 años más tarde se profundizaron y generalizaron para el tratamiento de depresiones, angustias, esquizofrenia y otros cuadros clínicos, al confirmarse su efectividad en varios meta análisis.

Una de sus fortalezas como maestro fue su compromiso consecuente con sus discípulos, acompañándonos en nuestra migración del hospital psiquiátrico al hospital general, y desde este al Consultorio de atención primaria, a los clubes de alcohólicos y al trabajo en las poblaciones. Estuvo junto a nosotros en el Barros Luco, en el Consultorio Santa Anselma y en la población la Victoria, y también nos fue a apoyar en el desarrollo del programa de salud mental de Antofagasta. Dedicó tiempo a cada uno de nosotros en nuestras tesis y proyectos de investigación, ayudándonos a escribir nuestras primeras presentaciones a congresos y primeros artículos en revistas de salud mental y psiquiatría. $Y$ hasta hace muy pocos años seguía colaborando con su producción intelectual en la formulación de políticas del M inisterio de Salud.

Marconi, el luchador social. M ás allá de la investigación y la docencia, $M$ arconi fue un hombre comprometido con la realidad de su país y con los esfuerzos para mejorarla. De la erudición universitaria, el psicoanálisis y la clínica, dio un gran salto hacia la epidemiología, los planes de salud pública y los programas intracomunitarios, como búsquedas incansables de elevar el nivel de salud mental de la población.

El liderazgo de M arconi generó en el Área Sur de Santiago, en solo 4 años, entre 1969 y 1973, un significativo movimiento social en torno a la salud mental. Los líderes poblacionales se capacitaban y multiplicaban, más de 30 clubes de alcohólicos en recuperación se formaron 0 reactivaron, numerosos curas y monjas se comprometían en programas de alcoholismo y salud mental en las poblaciones donde vivían, los con- sultorios de atención primaria incorporaban prestaciones de salud mental, se efectuaban jornadas de participación masiva, surgían experiencias pilotos innovadoras, tales como grupos de apoyo psicológico para neurosis y jardines infantiles comunitarios, entre mucho otros desarrollos.

$\mathrm{Ni}$ la dictadura ni las traiciones aplacaron su espíritu de lucha. Si bien los programas intracomunitarios fueron cercenados, M arconi siguió influyendo en la realidad a través de la formación de profesionales en alcoholismo, los cuales replicaron programas de atención en distintos puntos del país. También lo vimos involucrarse en el Hospital Psiquiátrico el Peral, luchando por mejorar las condiciones infrahumanas en que se encontraban sus internos en la década del 70, aportando con elementos técnicos y de defensa de derechos humanos.

Con el retorno a la democracia, sus análisis y propuestas contribuyeron enormemente al desarrollo de los Planes de Salud Mental, locales y nacionales. Lo encontramos participando y emocionándose, el 91, en el Estadio Italiano, y el 98, en el edificio Diego Portales, en las dos grandes asambleas donde se plasmaron los cimientos de los dos Planes $\mathrm{N}$ acionales de Salud M ental.

A través de estas imágenes de $M$ arconi como genio, Marconi como maestro y Marconi como luchador social, hemos querido estar junto a él en este momento con nuestro reconocimiento y nuestra gratitud de discípulos. Dedicarle también el reciente honor recibido por Chile junto a Brasil, de parte de la Organización Panamericana de la Salud y de la Organización M undial de la Salud, como los dos Planes Nacionales de Salud Mental de mayor desarrollo en Latinoamérica y el Caribe.

Gracias Profesor M arconi por tus ideas geniales, gracias por tu enseñanza comprometida y gracias por tu lucha por un mundo mejor.

Santiago, N oviembre, 2005. 